УДК 340.12

DOI https://doi.org/10.32849/2663-5313/2020.5.63

Наталія Гураленко,

докт. юрид. наук, доиент,

доцент кафедри людсъких прав

Чернівещького начіонального університету імені Юрія Федъковича

\title{
СВОБОДА ЯК АКСІОМАТИЧНА ОСНОВА ВІДПОВІДАЛЬНОСТІ
}

У статті свобода визначається як можливість суб'єкта діяти самостійно й незалежно, досягати своїх иілей та інтересів, не порушуючи при иьому прав інших, необхідність нести позитивну (перспективну) й негативну (ретроспективну) відповідальність за власні дії та вчинки. Аксіоматичною основою свободи є не вседозволеність чи безкарність, а відповідальне самовизначення. Відповідальність виявляє себе як двоєдиний феномен: з одного боку, вона передбачає усвідомлення наслідків самореалізаиї свободи, а з іншого - усвідомлення людиною обов'язків не тільки перед собою, а й перед суспільством за наслідки вільно вибраних дій. Відповідальність виступає тією соціальною вимогою, яку адресує суспільство своїм членам. Суть иієї вимоги - необхідність та обов'язковість оиінки суб'єктом власних дій з точки зору належного і неналежного.

Свобода - необхідний атрибут, істотна передумова відповідальності (як позитивной, так i негативної). Обгрунтовано тезу, що свобода - це вибір, нема вибору - нема й відповідальності. Взаємозв'язок свободи й відповідальності має соціальний і суб'єктивно-індивідуальний вимір, який проявляється у тому, що вибір правомірної чи протиправної моделі поведінки залежить не тільки від об'єктивної сочіальної дійсності, а й від сумління, переконань, потреб, інтересів, розумових здібностей окремого суб'єкта. Усвідомлення особистістю своєї свободи, межі якої визначаються правом, виступає однією з найважливіших гарантій відповідальності людини і суспільства в иілому.

Зауважено, що оскільки всезагальної та повної свободи не існує (рівнозначна свавіллю), реалізувати свободу можливо лише за умови ї̈ правового обмеження. Сутність права полягає в регулюванні поведінки людей таким чином, щоб свобода одного суб'єкта узгоджувалась зі свободою інших на підставі взаємоповаги, взаємовідповідального ставлення, неухильного виконання своїх обов'язків. Акиентовано увагу на тому, що лише свобода, обмежена правовими нормами, може забезпечити иілісність і стабільність людських взаємовідносин, запобігти свавіллю, спрямованому на порушення прав і свобод інших.

Ключові слова: свобода, відповідальність, норма права, правозастосовна діяльність, цінності права, детермінізм, індетермінізм.

Постановка проблеми. У правовій доктрині панує позиція, згідно з якою категорія свободи характеризується нечіткістю, неоднозначністю та є одним із найскладніших об'єктів пізнання. «Необхідний елемент демократичного режиму» чи «пафосне гасло» - кожен інтерпретує свободу по-різному. Беззаперечною залишається тільки її провідна роль у визначенні природи людини, її сутності та існування. Адже створити простір для творчої самореалізації особистості у всіх сферах соціального життя - це передусім процес трансформації свободи як можливості в одну з життєво важливих цінностей цієї особистості. Ïї аксіоматичною основою виступає не вседозволеність чи безкарність, а відповідальне самовизначення. Останнє при цьому передбачає: по-перше, узгодженість автономної волі (внутрішньої властивості суб'єкта) і волевиявлення (iї зовнішнього прояву); й по-друге, можливість відрізнити свободу від свавілля, безпосередніми наслідками якого є різного роду зловживання та порушення прав інших осіб.

Стан розробленості проблеми. Вагомий внесок у дослідження різноманітних юридичних і філософських проблем, які безпосередньо стосуються загальнотеоретичних характеристик категорії свободи, їі місця в сучасній правовій дійсності, онтологічного змісту та взаємозумовленості із відповідальністю здійснили: С. Алексєєв, О. Ашибокова, Р. Байніязов, В. Баранов, М. Бердяєв, Є. Бурлай, Ф. Веніславський, О. Волков, Г. В. Ф. Гегель, О. Грищук, Ю. Дмитрієнко, О. Донченко, С. Зайцева, І. Кант, Б. Капустін, А. Козловський, О. Костенко, С. Максимов, А. Малиновський, М. Матузов, В. Нерсесянц, Ю. Оборотов, М. Олексюк, Л. Петрова, В. Селіванов, Л. Щеннікова, Т. Яценко та ін.

Метою дослідження $\mathbf{\epsilon}$ аналіз свободи як аксіоматичної основи відповідальності. 
Виклад основного матеріалу. Враховуючи фактори дієвості свободи, останню можна охарактеризувати з позиції двох аспектів: по-перше, як зумовлену об'єктивними обставинами можливість діяти відповідно до вимог реальної дійсності (концепція детермінізму) й, по-друге, як сутнісну константу у визначенні індивіда як самостійно діючого суб'єкта, наділеного можливістю вибору відповідно до своїх потреб, бажань та цілей (концепція індетермінізму).

Свобода - можливість виражати свою волю, робити вибір, приймати рішення «власними силами», незалежно від якогось стороннього впливу чи дії. Водночас власний вибір немислимий, по-перше, без особливої вибірково-аналітичної активності свідомості, інтуїції, несвідомого й моральних сил, що в результаті внутрішнього протиборства мотивів мобілізуються на самостійне, відповідальне здійснення вибору, ухвалення рішення та його реалізацію, й, по-друге, насамперед без внутрішньої свободи. У такому випадку суть природного призначення свободи зводиться до того, що свобода постає як сам факт вибору. I чим більше вибору, тим більше свободи. Але тільки можливістю вибору свобода не визначається Наявність вибору, яка є в суб'єкта в конкретній ситуації, стає об'єктивним фактом, який ще не означає свободу в повному розумінні слова. Це всього лише свобода потенційна, можливість свободи. Маючи свободу вибору, можна залишатися невільним, діючи проти необхідності, проти інтересів і розвитку суспільства.

Особистісний вибір переростає у свободу тільки за умови усвідомлення й розуміння всього комплексу інтересів спільноти. Водночас наявність вибору може і не зумовити досягнення свободи - у разі, коли він виявиться відкритим нехтуванням необхідністю, випадковістю, що суперечить внутрішньому розвитку дійсності. Аналізуючи вищесказане, можна констатувати той факт, що свобода та особистісний вибір - не одне й те саме, хоча вони і тісно взаємопов'язані й підтверджують один одного. Як зауважуе 3 цього приводу С. Левицький, «філософська думка впродовж багатьох століть односторонньо зосереджувалася на свободі, яку розуміли як вибір, не враховуючи, що справжня свобода означає дещо більше, ніж тільки вибір. Вона означає творчий пошук нових шляхів і можливостей» [2, с. 24]. Аналогічної позиції дотримується й М. Бердяєв, на думку якого, «характеристика свободи як вибору $\epsilon$ ще формальним визначенням свободи. Це лише один із моментів свободи. Справжня свобода виявляється не тоді, коли слід виби- рати, а тоді, коли вже зроблено вибір. Тут ми приходимо до нового визначення свободи реальної як внутрішньо творчої енергії. Лише через неї можна творити цілком нові форми життя, нове життя суспільства й світу» [1]. Свобода не статична, а динамічна. Там, де вичерпується дух творчості й усвідомлення морального закону, там навіть за наявності формальних орієнтирів свобода може переростати у свій антипод - свавілля.

Будучи основою буття, свобода породжує нове, те, чого не було ще ніколи, що не зв'язане жодними нормами; вона постає як діяльність самовизначення, саме мислення $[7$, c. 69]. Такий контекст розуміння свободи можна інтерпретувати в правозастосовній діяльності як специфічну форму мислення, експлікацію гносеологічних, орієнтаційних, інтелектуальних та творчих операцій, важливий засіб самореалізації правника, що передбачає не тільки техніко-юридичне, логічне пристосування конкретної ситуації до наявних нормативних актів чи навпаки, але й визначення ним свого правового місця в загальній структурі відносин, усвідомлення характеру своєї відповідальності, свого обов'язку.

Взаємозв'язок свободи й відповідальності має соціальний й суб'єктивноіндивідуальний вимір, який проявляється у тому, що вибір правомірної чи протиправної моделі поведінки залежить не тільки від об'єктивної соціальної дійсності, а й від сумління, переконань, потреб, інтересів, розумових здібностей окремого суб'єкта.

Юридичний аспект проблеми означає з'ясування питання, за що, тобто за яку саме поведінку, може наставати відповідальність. У чинному вітчизняному законодавстві 3 приводу цього питання однозначно сформульовано, що підставою відповідальності $€$ наявність складу правопорушення, елементами якого є: об'єкт злочину; об'єктивна сторона злочину; суб'єктивна сторона злочину; суб'єкт злочину. 3 точки зору філософії права до суб'єктивної сторони складу правопорушення слід віднести свободу волі. Адже психічні внутрішні процеси, які відбуваються у свідомості особи у зв'язку з вчиненням нею суспільно небезпечного діяння, за справедливим зауваженням О. Донченко, власне і свідчать про вільне спрямування іiі волі, ставлення до суспільно небезпечного діяння та його наслідків. Якщо людина наділена свободою волі, вона може і повинна не тільки приймати рішення про вчинення певних дій, але й нести відповідальність за свої дії. І це, на думку вченої, аргументується тим, що «світ постає перед нею не як хаотичне нагромадження людських дій, як система 
еталонів, орієнтуючись на які вона повинна обрати власний варіант поведінки» [5, с. 36]. Відповідно, методологічною основою вирішення проблеми взаємозумовленості свободи і відповідальності слід вважати підхід, відповідно до якого соціальною передумовою притягнення людини до відповідальності за суспільно значиму поведінку є свобода волі, що розуміється як наявність можливості вільно вибирати спосіб поведінки.

Людина - вільна істота, їй притаманна свобода вибору, тобто вона здатна самостійно, осмислено, з урахуванням можливих наслідків вибирати свій життєвий шлях. Така свобода є відповідальною, тобто особа несе відповідальність за вибране або вчинене нею. Іншими словами, якщо людина користується свободою, складниками якої $€$ не тільки спектр можливостей, але й цілеспрямована позиція по відношенню до оточуючого світу, то вона має відповідати за неї, за те, як вона її реалізує. Будь-яка ситуація не призводить сама собою (без рішення суб'єкта) до правопорушення. Вчиняти проступок чи ні - завжди вирішує, завдяки своїм вольовим та інтелектуальним здібностям, суб'єкт. Інакше, якщо б об'єктивні умови допускали можливість лише одного варіанту поведінки і виключали б участь свідомості у виборі вчинків, слід було би зняти питання про відповідальність людини за свою поведінку. 3 цього приводу Н. Лазорик резонно зауважує: «Поняття свободи та відповідальності тісно переплітаються між собою. I це очевидно, адже, не маючи свободи, людська особистість була би позбавлена можливостей відповідати за свої вчинки, тоді вони поставали б як вираження чужої волі, провідником і знаряддям якої виявилась дана особа, або ж як результат сліпого випадку, прояв байдужої гри природних сил» [6, с. 61].

Необхідним атрибутом, аксіоматичною основою та супроводжуючим змістовим елементом відповідальності є свобода. Філософсько-правова природа відповідальності зводиться до двох аспектів: перспективної (позитивної) відповідальності - внутрішнього усвідомлення особистістю своїх обов'язків перед суспільством, розуміння в цьому сенсі значення своїх дій, і ретроспективної (негативної) відповідальності - негативної реакції суспільства й держави на вчиненні дії, які суперечать загальнообов'язковим нормам.

Відповідальність є невіддільною від свободи. Вона фіксує зрілість свободи людини у виборі цінностей, цілей, засобів і способів їх досягнення, у розумінні наслідків своїх діянь не тільки для себе, але й для інших. Отологічний вимір відповідальності суб'єктів права повинен характеризуватися продуманістю, виваженістю, обгрунтованістю рішень, урахуванням всіх обставин і можливих наслідків - готовністю відповідати за свої вчинки. Розглядаючи свободу як аксіоматичну основу відповідальності, слід завжди враховувати пропорційність діапазону свободи суб̆'єкта із діапазоном його відповідальності. До свавілля призводить тільки необмежена свобода. Саме тому свобода суб'єкта права в процесі його діяльності також повинна мати межі. У зв'язку із цим виникає ряд запитань, на які сучасність змушена правильно відповісти, а саме: як визначити межі вільного правового розсуду, щоб уникнути сваволі? що може бути гарантією проти виникнення останньої?

Свобода не може бути реальною, якщо вона не має правової форми і не втілюється в життя через механізм правового регулювання. Останнє зумовлюється тим, що, по-перше, саме право за своєю вихідною суттю є формою, створеною людьми, логічно й історично призначеною бути інститутом, покликаним упорядковувати свободу, додавати їй визначеності і забезпечуваності, а звідси - і людського змісту, істинно людської цінності; й по-друге, якщо відсутній механізм практичного втілення, то йдеться тільки про свободу-можливість і людина буде не здатна реалізувати свою самобутність через відсутність визначеності, а головне, гарантованості.

Свобода - це можливості, межі яких окреслені правовими нормами права [9]. Свобода не характеризується статичністю, це соціальне динамічне явище, яке за своєю сутністю одночасно є й метою, й засобом, й умовою повноцінної людської діяльності як складової частини суспільного розвитку. Пошук свободи, її прагнення безмежні. Однак формальне закріплення їі окреслено рамками права. Право, як регулятивний механізм, безперервно забезпечує діючий порядок та дисципліну у суспільстві, окреслює сферу індивідуальної автономії [3, с. 34]. Якщо немає права - немає й реальної можливості захистити свободу, надати їй форму, завдяки якій вона може перетворитися з можливості на дійсність.

Основна мета права - закріпити межі такого варіанту поведінки, який найбільше відповідає інтересам індивідів та оптимальному розвитку суспільства. Здатність регулювати суспільні відносини й спрямовувати суспільний розвиток у потрібному напрямі дозволяе визначити право як цивілізаційний механізм, що сприяє досягненню свободи учасниками правових відносин. Людина повинна не просто знати, що вона вільна, але й чітко уявляти ту міру свободи, яка є оптимальною в правовому 
просторі цивілізованого суспільства. Свобода у такому контексті виступає не тільки як абстрактна соціальна цінність, а й як певний правовий порядок взаємодії прав, можливостей суб'єктів та обов'язків, зобов'язань і відповідальності перед іншими людьми, суспільством і державою.

\section{Висновки}

Свобода - це специфічний спосіб буття індивіда, можливість суб'єкта діяти самостійно й незалежно, досягати своїх цілей та інтересів, не порушуючи при цьому прав, свобод інших; це аксіоматична основа позитивної (перспективної) та негативної (ретроспективної) відповідальності за власні дії та вчинки. Оскільки всезагальної та повної свободи не існує (рівнозначна свавіллю), відповідально реалізувати свободу можливою лише за умови її правового обмеження. Сутність права полягає в регулюванні поведінки людей таким чином, щоб свобода одного суб'єкта узгоджувалась зі свободою інших на підставі взаємоповаги, взаємовідповідального ставлення, неухильного виконання своїх обов'язків. Правові межі, що окреслюють свободу, мають як об'єктивний характер (окреслюються чинним законодавством; позитивним, об'єктивним правом), так і суб'єктивний (визначаються самим суб'єктом права, його внутрішнім станом).

\section{Список використаних джерел:}

1. Бердяев Н. А. Царство духа и царство кесаря. Москва : Республика, 1995. URL : http:// krotov.info/library/02_b/berdyaev/1947 4000. html (дата звернення: 04.04.2020).

2. Богданов В. Логика становления и семантика понятия свободы. Вестник Таганрогского государственного педагогического института. 2006. № 2. C. $10-26$.

3. Волков А. Юридико-философские пределы свободы в самосознании человека. Философия права. 2008. № 4 (29). С. 32-36.

4. Грищук О. Свобода як філософсько-правова цінність. Науковий вісник Львівського державного університету внутрішніх справ. 2007. Вип. 1. C. $193-204$

5. Донченко О. Свобода як передумова кримінально-правової відповідальності. Наyковий вісник Чернівещького університету. 2006. Вип. 311. С. 34-38.

6. Лазорик Н. Свобода і відповідальність як філософські та соціологічні категорії. Науковий вісник Чернівецького університету. 1998. Вип. 35. С. 61-64.

7. Разгильдиева М. Б. Правовое убеждение и принуждение: теоретические основы (на примере финансового законодательства) : монография. Москва : Юрлитинформ, 2012. 272 с.

8. Селіванов В. Свобода, відповідальність і моральність. Юридический вестник. 2001. № 2. C. $84-89$.

9. Семенюта Н. Право - социально необходимый ограничитель свободы. Право $u$ политика. 2003. № 2 (38). C. 4-15.

The article defines freedom as the ability of the subject to act individually and independently, to achieve their goals and interests, without an impact on the rights of others and the importance to take positive (active) and negative (retrospective) responsibility for their own actions and deeds. The axiomatic basis of freedom is not permissiveness or impunity, but responsible self-determination. Responsibility manifests itself as a dual phenomenon: on the one hand, it presupposes awareness of the consequences of the self-realization of freedom, and on the other - its responsibility not only to yourself, but also to society for the consequences of freely chosen actions. Responsibility is the social demand that society addresses to its members. The essence of this requirement is the necessity and obligation to the subject's assessment of his own actions from the dependent and independent vieres.

Freedom is a necessary attribute, an essential prerequisite for responsibility (both positive and negative). The thesis is that freedom is a choice, if there is no choice - there is no responsibility. The connection between freedom and responsibility has a social and subjective measures. It is manifested that the choice between legal and illegal model of behavior depends not only on the objective social reality, but also on the conscience, beliefs, needs, interests, mental abilities of the individual. Awareness of the individual of his freedom, the bounds of which are determined by law, is one of the most important guarantees of responsibility of a person and society in general.

It is noted that since there is no universal and complete freedom (equivalent to arbitrariness), the realization of freedom is possible only if it is legally restricted. The essence of law is to regulate the behavior of people so that the freedom of one subject is consistent with the freedom of others on the basis of mutual respect, mutual responsibility, strict performance of their duties. Emphasis are placed on the fact that only freedom limited by norms of law can ensure the integrity and stability of human relations, prevent arbitrariness aimed at affecting the rights and freedoms of others.

Key words: freedom, responsibility, norms of law, law enforcement activity, values of law, determinism, indeterminism. 